\title{
Nature 論文選定に関する俗説
}

\section{Nature's choices}

2010 年 2 月 18 日号 Vol. 463 (850)

Nature に掲載される研究論文に関して、選定方法と選定理由について誤つた俗説がなお幅を利かせている。 それらについて明確に反論する。

科学が導き出した結論に対する論争は、 知らないうちに科学に対する国民の信頼 を損なう効果がある。それは気候変動に 関する新聞や雑誌の報道からも明らか だ。学術論文誌は、科学のプロセス（創 造過程）を伝えるという重要な役割を担 うため、我々が Nature に掲載する研究 論文を選ぶ方法をきちんと説明し、研究 コミュニティーの内外で知り得た「誤解」 をいくつか取り上げて論じることは、意 味があると思われる。

一向に消える気配がない第一の俗説は 次のようなものだ。Natureの編集者は インパクトファクターを上げるため、投 稿論文 (昨年は約 1 万 6000 本) の中か ら高い引用率が見込まれる論文を探し出 そうとしている、と。もちろん我々は、 そんなことはしていない。論文の被引用 数は予測が難しく、重要性の尺度として の信頼性も低いからだ。

一例として、2006 年 6 月に発表され た有機合成化学の 2 つ論文を挙げよ う。第一の論文は「3 段カスケード有機 触媒反応における 4 つの立体中心の制御 (D. Enders et al. Nature 441, 861-863; 2006)」で、被引用数は、2009 年後半 までに 182 となり、2006 年に Nature に揭載された化学論文のうち 4 番目に 被引用数が多かった。第二の論文は「2キヌクリドニウム・テトラフルオロボ レートの合成および構造解析 (K. Tani and B. M. Stoltz Nature 441, 731-734; 2006)」で、2009 年後半までの被引用 数は 13 であった。しかし米国化学会が 発行する雑誌 Chemical and Engineering
Newsにおいて、傑出した研究成果と評 されたのは第二の論文の方だった。

実際、Nature に掲載される論文のう ち、被引用数が数十回のものは、数百回 のものよりもはるかに数が多い。それで も Nature のインパクトファクターで大 きな割合を占めるのは、後者の方なのだ。 我々は、本誌に掲載されるすべての論文 に誇りをもっている。

もう 1 つ長く語り継がれている俗説 に、「レフェリー（査読者）の 1 人が論 文不受理と判断すれば、論文は揭載さ れない仕組みになっている」というもの がある。しかし、レフェリー全員が失望 した論文を我々独自の価値評価に基づ いて掲載した事例が、昨年でも数件あっ た。こうした内部評価を下すことは、 我々の担う役割の中でも常に中心的な ものとなってきた。これは、Natureに 編集委員会が設置されてこなかったこ とによる。Natureの編集者は、1 年の うちの数週間は学会に出席したり研究 室を訪問し、文献に目を通すことも決し て怠らない。

掲載可否の審査対象となる論文は、2 人以上のレフェリーが審査にあたり、学 際的な論文の場合には、レフェリーが増 員される。技術的問題点が指摘されれ ば、我々は適切な対応を取り、論文につ いて重要と思われる点、欠けていると思 われる点に関するレフェリーの意見を尊 重する。しかし、論文に書かれた手順や 方法が深い洞察力に基づいているかどう か、あるいはデー夕源としての価值、さ らには画期的な技術に結びつく可能性、
といった要件に基づいて最終判断をする のは我々なのだ。

また我々は、特定の著者の身元あるい は所在地によって決定が左右されない、 という厳しい原則に基づいて運営して いる。Nature 掲載論文のほとんどすべ ては、複数の著者によっており、複数の 出身国になっていることも多い。たまた ま著名な科学者や話題の科学者が著者 に名を連ねた論文が不受理になること も珍しくない。

「特定の研究分野では、少数の特権的 なレフェリーに依存している」という俗 説もある。しかし実際に、Natureでは、 昨年 1 年間に約 5400 人のレフェリーを 起用し、常に新しいレフェリー、特に最 新技術に直接かかわっている若手専門研 究者を採用している。また、レフェリー は、科学先進国各国から起用している。 そのレフェリーが Nature で論文発表し ているかどうかは関係ない。ただし、対 応の遅さに定評のある研究者の採用は控 えている。競争の激しい分野では、著者 の希望と我々独自の判断に基づいて、利 益相反が明らかなレフェリーの採用は回 避している。

学術論文誌に関する俗説は、これから も語り継がれていくであろう。我々ので きることは、我々が結集できる最高の科 学を読者に提供するという飽くなき探求 を続けることであり、ここで述べた編集 過程の堅牢性と客観性を、今後もできる かぎり保っていく努力を続けることだと 信じている。

(翻訳 : 菊川要) 